DOI:10.30842/ielcp2306901522113

A. A. Eseleva

\title{
THE LANGUAGE OF MYSTICS IN MIDDLE ENGLISH TEXTS BY JULIAN OF NORWICH AND MARGERY KEMPE*
}

\section{А. А. Еселева. Особенности среднеанглийской мистической прозы Юлианы Нориджской и Марджери Кемп}

В статье в сопоставительном аспекте рассматриваются первые женские мистические произведения английской литературы: «Откровения Божественной Любви» Юлианы Нориджской и «Книга Марджери Кемп».

Ключевые слова: среднеанглийская мистика, Юлиана Нориджская, Марджери Кемп.

The present paper focuses on two famous Medieval English writings that have much in common: 'A Revelation of Divine Love' by Julian of Norwich and 'The Book of Margery Kempe'. Both writings belong to the first books ever composed by women in the English language. Both appeared in Norfolk within the timespan of the second half of the fourteenth and the first half of the fifteenth centuries. Both can be attributed as spiritual autobiographies, and as such they also represent the first vernacular works of the genre for the English language. Since the second quarter of the twentieth century the writings by Julian and Margery have been profoundly studied. They are, however, more often analyzed independently than compared and contrasted in extensive research literature. The aim of the present paper is to show by means of comparison that already at an early stage English mystical writings displayed certain genrespecific and distinctive linguistic features.

Julian (1342 - after 1416) was an anchoress at Norwich. Little is known about her life. Julian's account of her illness allows us to establish the year of her birth: she was thirty and a half in 1373

\footnotetext{
* The present article is a version of the paper presented at the workshop Methoden der Erforschung deutschsprachiger geistlicher Prosa des Mittelalters in November 2017 in Augsburg. I am grateful to Prof. Freimut Löser for the fascinating opportunity to discuss the Middle English mystics by Julian and Margery in comparison with Medieval German spiritual prose, and to the participants of the workshop for their valuable comments. I would like to thank Docent Matti Kilpiö and Docent Leena KahlasTarkka from University of Helsinki for their generous and kind help at an earlier stage of this research. Any inaccuracies are my responsibility.
} 
when she fell ill and was healed through her visions. Other sources include the wills of the citizens of Norwich who left certain sums of money to the anchoress at St.Julian's church as late as 1414 and 1416, the Amherst MS (British Library, Add. MS 37790) with the assertion that the anchoress who composed the work was still alive in 1413, and Margery Kempe's account of her meeting with Julian around 1413.

The text by Julian exists in earlier and in later versions. These have been traditionally attributed as Short text and Long text, respectively. The Short text, as Julian claims, was composed directly after her visions (thus, in 1373), while the Long text (composed in mid-1390s or later) appeared as a result of many years' reflection on the visions and contains numerous additions and expansions which influence the discourse perspective. In a recent edition, N. Watson and J. Jenkins designate the two works by their initial phrases: $A$ Vision Showed to a Devout Woman (or A Vision) and A Revelation of Love (or A Revelation). Three seventeenth century MSS representing two traditions of $A$ Revelation came down to us ${ }^{1}$, but just a single mid-fifteenth century Amherst MS contains $A$ Vision. In its language, the text of $A$ Vision represents a mixture of Eastern and Northern dialects. This suggests its complicated text transmission history, or Überlieferungsgeschichte; the text may had undergone no less than three rewritings before it reached the present state ${ }^{2}$.

Margery Kempe (1373 - ca. 1439) was the daughter of John Brunham, mayor of Lynn, the mother of fourteen children in her marriage to John Kempe, a visionary and a pilgrim. Her book discovered in 1932 in the single surviving MS (British Library, Add. MS 61823) provides extensive information not only about her spiritual practices, but also on related aspects of her family and social life ${ }^{3}$.

\footnotetext{
${ }^{1}$ These are British Library, Sloane MS 2499 (early 17th c.) and Sloane MS 3705 (late 17th c.), along with Paris, Bibliothèque Nationale, MS Fonds Anglais 40 (early or mid-17th c.). Excerpts from A Revelation also appear in: Westminster Cathedral Treasury MS 4 (early 16th c.) and St. Joseph's College Library, Upholland, Lancashire (17th c.)

${ }^{2}$ Further information on Julian and her writings is to be found in e.g. Glasscoe 1976, Dresvina 2010, Watson \& Jenkins 2006, and McGinn 2016. ${ }^{3}$ Before the discovery of the MS only a short devotional excerpt from the Book published in early sixteenth century by Wynkyn de Worde was known which created the wrong impression of the work. Further information on Margery and her Book is available in e.g. Windeatt 2004, Staley 2001, and McGinn 2016.
} 
The works by Julian and Margery can be contrasted at various levels. The first question that arises when we deal with a medieval manuscript is that of authorship. Both Julian and Margery claim being unlettryd. The meaning of the term might be different, though: while with Margery it most certainly means 'illiterate', with Julian it might mean 'unable to write in Latin'. Margery was read to by her priest, and thus, gained her knowledge of contemporary contemplative writings, such as The Cloud of Unknowing by Walter Hilton, the Revelations of St.Bridget of Sweden, Incendium Amoris by Richard Rolle, and also of literary conventions which she later made use of while composing her own book. According to B. Windeatt, "the Book suggests someone very much aware of contemporary devotional traditions and trends, and not uninformed of how saintly women might be represented" (Windeatt 2004: 9). Julian's texts suggest deeper knowledge, including that of patristic texts, and it could be the case that she was in fact very well 'lettryd' not only in English, but also in Latin $^{4}$, but needed to present herself to her audience in this way, as her book was meant 'for those who could not read a letter'.

A further observation is that the two versions by Julian, $A$ Vision and $A$ Revelation, should be treated separately in this respect. Though it is generally accepted that Julian authored both versions, it might be suggested that the later revision of the text rich in theological reasoning was done by someone else, for instance, some Benedictine cleric. Let us consider excerpts describing the first vision in both versions.

(1) And I was answerde in my resone and be the felinges of my paynes that I schulde die. (...) And in this, sodaynlye I sawe the rede blode trekille downe fro under the garlande alle hate, freshlye, plentifully, and livelye, right as methought that it was in that time that the garlonde of thornes was thyrstede on his blessed hede. Right so, both God and man, the same sufferde for me. I conseyvede treulye and mightelye that it was himself that shewed it me, withouten any meen. (A Vision, Watson \& Jenkins 2006: 65-69).

(2) And I understode in my reason and by the feeling of my paines that I should die. (...) And in this, sodenly I saw the red bloud trekile downe from under the garlande, hote and freshely, plentuously and lively, right as it was in the time that the garland of thornes was pressed on his blessed head. Right so, both God and man, the same that sufferd for me. I conceived truly and mightly that it was

\footnotetext{
${ }^{4}$ A well-known statue at the Norwich Cathedral depicts Julian with her book and a quill in her hand.
} 
himselfe that shewed it me, without any meane. And in the same shewing, sodeinly the trinity fulfilled my hart most of joy. And so I understode it shall be in heaven without end, to all that shall come ther. For trinity is God, God is the trinity. The trinity is our maker, the trinity is our keper, the trinity is our everlasting lover, the trinity is our endlesse joy and our blisse, but our lord Jesu Christ and in our lord Jesu Christ. And this was shewed in the first sight and in all. For wher Jhesu appireth the blessed trinity is understand, as to my sight. (A Revelation, Watson \& Jenkins 2006: 131-137).

Julian describes her vision in a way that makes the reader get involved in a primary mental process. Julian's writings especially in description of the visions display features of oral speech. These might either prove that she in fact dictated her book, or be a stylistic device. The later addition is clearly visible in example (2). It was obviously added with a different aim - to teach, to persuade, to provide theological ground for the experience, and, not least, to demonstrate Julian's adherence to the dogmates of the Church. As for Margery, she certainly dictated her book and even described at length the troubles she faced trying to do so. Here is how she describes her first vision:

(3) than on a tym, as sche lay aloone and hir kepars wer fro hir, owyr mercyful Lord Christ Jhesu, evyr to be trostyd, worshypd be hys name, nevyr forsakyng hys servawnt in tyme of nede, aperyd to hys creatur whych had forsakyn hym in lyknesse of a man, most semly, most bewtyvows, and most amyable that evyr mygth be seen wyth mannys eye, clad in a mantyl of purpyl sylke, syttyng upon hir beddys syde, lokyng upon hir wyth so blyssud a chere that sche was strengthyd in alle hir spyritys, seyd to hir thes wordys: 'Dowtyr, why hast thow forsakyn me, and I forsoke nevyr the?' And anoon, as he had seyd thes wordys, sche saw verily how the eyr openyd as brygth as ony levyn, and he stey up into the eyr, not rygth hastyli and qwykly, but fayr and esly, that sche mygth wel beholdyn hym in the eyr tyl it was closyd ageyn (Windeatt 2004: 55-56).

Margery retells her visionary experience in the third person. Her syntax is not at all as simple and clear as Julian's. However, both writings make use of prose rhythm. M. Glasscoe notes on A Revelation: "The repeated construction in this wisdom ... made, this gretenes ... fulfilled, introduces an explanatory insistence" (Glasscoe 1976).

In Margery's visions the Lord speaks to her in a fatherly manner (example 3). On the contrary, Julian tends to provide an interpretation of the meaning of divine words, e.g.: 
(4) Fulle merelye and gladlye oure lorde lokyd in to hys syde and behelde and sayde this worde: Loo, How I lovyd the, as $3 \mathbf{y f}$ he hadde sayde: My childe, zif thow kan nought loke in my godhead, see heere Howe I lette opyn my syde, and my herte be clovene in twa, and lette oute blude and watere alle pat was thare yn. and this lykes, me and so wille I that it do the.

(5) I love thee and thou lovist me; and our love shal not be departed in two, and for thi profit I suffre'. And all this was shewid in gostly vnderstondyng sayand these blissid words: 'I kepe the full sekerly'.

The question of authority is crucial for both writings. As E. Dutton puts it, in medieval texts, "authority came not from originality but from conformity to tradition" claiming that Julian's text should be considered a skillful imitation of a compilation. For Margery, her "conformity to tradition" is an imitation of the ways of representation of saintly women. The question of self-representation is important for both authors, but for Margery it is almost crucial: Margery's book is an apology, "a defense of her unusual way of life rather than a meditation" (Windeatt 2004). The common imagery adopted in the writings by Julian and Margery should also be mentioned: an extraordinary experience starts when a visionary suffers from an illness which ends with the vision. In the case of Julian, this is a physical, almost fatal illness, and Margery is suffering from mental disorder when her first vision occurs.

Both writings describe spiritual development of a medieval woman, though in their own way. Both authors are skillful in presenting their visions and themselves to the reader. The fact that, according to Margery, both visionaries met in 1413 emphasizes strong connection between these two very distinct works of the genre. Here is an excerpt of her account on their meeting:

... for the ankres was expert in swech thyngys and good cownsel cowd yevyn. The ankres, heryng the mervelyows goodness of owyr Lord, hyly thankyd God with al hir hert for hys visitacyon, cownselyng this creatur to be obedient to the wyl of owyr Lord God and fulfyllyn wyth al hir mygthys whatevyr he put in hir sowle, yf it wer not ageyn the worship of God and profyte of hir evyn-Cristen, for, yf it wer, than it wer nowt the mevyng of a good spyryte, but rather of an evyl spyrit. 'The Holy Gost mevyth nevyr a thing ageyn charite, and, yf he dede, he wer contraryows to hys owyn self, for he is al charite'. (Windeatt 2004: 119-123). 


\section{References}

Beer, F. (ed.) 1978: Julian of Norwich's Revelations of Divine Love. The Shorter Version. Heidelberg: Carl Winter, Universitätsverlag.

Dresvina, J. (ed.) 2010: Otkrovenija bozhestvennoj lubvi: dve redaktsii sredneanglijskogo teksta s parallelnym perevodom [Revelations of Divine Love: Two Versions of the Middle English Text, with a Parallel Translation]. Moscow: Russian foundation for education and science.

Дресвина Ю. (ред.) 2010: Откровения божественной любви: две редакиии среднеанглийского текста с параллельным переводом. М.: Русский фонд содействия образованию и науке.

Dresvina, J. \& N. Sparks (eds.) 2012: Authority and Gender in Medieval and Renaissance Chronicles. Cambridge: Cambridge Scholars Publishing.

Dutton, E. 2008: Julian of Norwich. The Influence of Late-Medieval Devotional Compilations. Cambridge: Brewer.

Glasscoe, M. (ed.) 1976: Julian of Norwich. A Revelation of Love. University of Exeter.

McGinn, B. 2016: Die Mystik im Abendland. Band 5: Vielfalt. Die Mystik in den Niederlanden, Italien und England (1350-1550). Herder.

Staley, L. (ed.) 2001: The Book of Margery Kempe. A New Translation, Contexts, Criticism. New York; London: W.W. Norton \& Company.

Stone, R. K. 1970: Middle English Prose Style: Margery Kempe and Julian of Norwich. The Hague; Paris: Mouton.

Watson, N. \& J. Jenkins (eds.) 2006: The Writings of Julian of Norwich. A Vision Showed to a Devout Woman and A Revelation of Love. Pennsylvania State University Press.

Windeatt, B. (ed.) 2004: The book of Margery Kempe. Cambridge: Brewer.

Summary. The paper analyzes and compares two famous Medieval English mystical writings, namely 'A Revelation of Divine Love' by Julian of Norwich and 'The Book of Margery Kempe', which belong to the first books ever composed by women in the English language. The questions of authorship and authority are discussed in the light of the language features used to describe a vision in both writings.

Key words: Medieval English Mystics, Julian of Norwich, Margery Kempe. 